\title{
ENDEMIC AND THREATENED TETRAPODS IN THE RESTINGAS OF THE BIODIVERSITY CORRIDORS OF SERRA DO MAR AND OF THE CENTRAL DA MATA ATLÂNTICA IN EASTERN BRAZIL
}

\author{
ROCHA, C. F. D., VAN SLUYS, M., BERGALLO, H. G. and ALVES, M. A. S. \\ Departamento de Ecologia, Instituto de Biologia Roberto Alcântara Gomes, Universidade do Estado do Rio de \\ Janeiro, UERJ, Rua São Francisco Xavier, 524, Maracanã, CEP 20550-019, Rio de Janeiro, RJ, Brazil \\ Correspondence to: Carlos Frederico Duarte da Rocha, Departamento de Ecologia, Instituto de Biologia Roberto \\ Alcântara Gomes, Universidade do Estado do Rio de Janeiro, UERJ, Rua São Francisco Xavier, 524, Maracanã, \\ CEP 20550-019, Rio de Janeiro, RJ, Brazil, e-mail: cfdrocha@uerj.br \\ Received December 11, 2002 - Accepted November 6, 2003 - Distributed February 28, 2005
}

(With 1 figure)

\begin{abstract}
Biodiversity corridors comprise a mosaic of land uses connecting fragments of natural forest across a landscape. Two such corridors have been established along the eastern coast of Brazil: the Serra do Mar and the Central da Mata Atlântica corridors, along which most of the coastal plains are restinga areas. In this study, we analyze the present status of the endemic and endangered terrestrial vertebrates of both corridors. We sampled 10 restingas in both corridors, recording species of amphibians, reptiles, birds, and mammals. Some restingas harbor a relatively large number of endemic species, and two main regions of endemism can be identified along the restingas of both corridors: the coastal restingas from northern Espírito Santo State to southern Bahia State (between Linhares, ES, and Trancoso, BA), and the coastal region between the restingas of Maricá and Jurubatiba, Rio de Janeiro State. Six species of terrestrial vertebrates considered threatened with extinction are found in the restingas of Serra do Mar and Central da Mata Atlântica biodiversity corridors (Liolaemus lutzae, Formicivora littoralis, Mimus gilvus, Schistochlamys melanopis, and Trinomys eliasi). The region located between the restinga of Maricá and that of Jurubatiba is of special relevance for the conservation of vertebrate species of the restingas of the corridors because a considerable number of threatened species of terrestrial vertebrates are found there. We strongly recommend efforts to develop checklists of threatened faunas for the States of Espírito Santo and Bahia.
\end{abstract}

Key words: biodiversity corridors, Atlantic Rainforest, restingas, terrestrial vertebrates, endemisms, extinction.

\section{RESUMO}

\section{Tetrápodos endêmicos e ameaçados nas restingas dos corredores de biodiversidade da Serra do Mar e Central da Mata Atlântica no leste do Brasil}

Corredores de biodiversidade compreendem um mosaico de usos do solo conectando fragmentos de vegetação natural ao longo da paisagem. Ao longo da costa leste do Brasil, dois corredores de biodiversidade foram estabelecidos: o da Serra do Mar e o Central da Mata Atlântica. A maioria das planícies costeiras ao longo desses dois corredores é constituída por restingas. Neste estudo analisamos o status atual das espécies de vertebrados terrestres endêmicas e ameaçadas nos dois corredores. Amostramos dez restingas nos dois corredores, registrando a ocorrência de espécies de anfíbios, répteis, aves e mamíferos. Algumas restingas apresentam número relativamente alto de espécies endêmicas e duas regiões principais de endemismos podem ser reconhecidas nas restingas ao longo dos corredores: as restingas costeiras do norte do Espírito Santo até o sul da Bahia (entre Linhares, ES, e Trancoso, BA) e a região costeira entre 
as restingas de Maricá e Jurubatiba, Estado do Rio de Janeiro. Seis espécies de vertebrados terrestres consideradas ameaçadas de extinção foram encontradas nas restingas dos corredores da Serra do Mar e Central da Mata Atlântica (Liolaemus lutzae, Formicivora littoralis, Mimus gilvus, Schistochlamys melanopis e Trinomys eliasi). A região localizada entre as restingas de Maricá e Jurubatiba é de especial relevância para a conservação de espécies de vertebrados das restingas nos corredores, pois nela foi encontrado elevado número de espécies ameaçadas. Recomendamos esforços para a elaboração de listas de fauna ameaçada para os Estados do Espírito Santo e Bahia.

Palavras-chave: corredores de biodiversidade, Floresta Atlântica, restingas, vertebrados terrestres, endemismos, extinção.

\section{INTRODUCTION}

Ecological corridors (environmental portions linking two or more fragments in order to re-establish connections of the fauna and flora between fragments to increase dispersion) and biodiversity corridors (which comprise mosaics of land, with various uses, connecting fragments of natural forest across a landscape (Center for Applied Biodiversity Science, 2000) are important strategies in conservation. Along the eastern coast of Brazil two biodiversity corridors have recently been established (Ministério do Meio Ambiente, 2002): (1) The Serra do Mar corridor that encompasses the forested remnants of the northern portion of Rio de Janeiro State to the middle region of São Paulo State, and (2) the Central da Mata Atlântica corridor that encompasses these remnants in southern Bahia State southward to the southern portion of the Espírito Santo State. Along these two biodiversity corridors most of the coastal plains are restinga areas (coastal sand-dune habitats).

The coastal region of Brazil is one of the country's most disturbed and exploited areas as a result of approximately 500 years of the intense human settlement that followed Brazil's discovery. The demographic density of the coastal zone has been comparatively high throughout recent centuries and in 2002 reached a mean value of $87 \mathrm{ind} . / \mathrm{km}^{2}$, which is approximately five times higher than the country's average of about 17 ind. $/ \mathrm{km}^{2}$ (Ministério do Meio Ambiente, 2002). As a result, the remaining vegetated coastal strips have been undergoing intense human impact, resulting in an increasing process of degradation of the coastal sand plains, sand dunes, and beach habitats (restingas) along most of the Brazilian coast (Rocha \& Bergallo, 1997; Araújo \& Lacerda, 1987; Araújo, 1991, 2000). A considerable portion of restinga areas in Brazil are being lost every year for housing (SOS Mata Atlântica/INPE/Instituto SocioAmbiental - Atlas dos Remanescentes Flo- restais da Mata Atlântica, 1998; SOS Mata Atlântica/INPE, 2001), although there is still no detailed quantification of remnants of restinga areas in the Central da Mata Atlântica and Serra do Mar corridors. Restinga habitats are relatively fragile environments due to their poor soil and in some areas the local environment is highly saline (Hay et al., 1981). As a consequence, the clearing of restinga vegetation results in further difficulties for habitat recomposition, especially with respect to vegetation.

Surprisingly, coastal restingas, despite being in the highest human density zone, remain one of the least-known environments, not only in biodiversity, but also regarding the present conservation status of their remnants. The best-known restinga areas in the corridors in terms of fauna and flora are those of Maricá and Jurubatiba in Rio de Janeiro State and, to a lesser extent, that of Setiba in Espírito Santo State. For most of the restinga areas of the two biodiversity corridors there is no information available, even on the species composition of terrestrial vertebrates.

In the present study, based on field data from our studies and inventories in coastal restingas, and data available in the literature, we analyzed the present status of endemic and endangered terrestrial vertebrates of the biodiversity corridors of Central da Mata Atlântica and Serra do Mar.

\section{METHODOLOGY}

To assess the present condition of endemic and threatened species of tetrapods in the restingas of both the referred-to biodiversity corridors we made:

1. Rio de Janeiro (RJ), Espírito Santo (ES), and Bahia (BA) states. The species inventories included restinga in the areas of both corridors, including five in the Serra do Mar corridor (restingas of Grumari, Maricá, Massambaba, Jurubatiba, and Grussaí) and four in the Central da Mata Atlânti- 
ca corridor (restingas of Setiba, Guriri, Prado, and Trancoso) (Fig. 1). Despite its biological relevance, one of the restinga areas sampled (Praia das Neves, Presidente Kennedy municipality, ES) is still not included in the area of the two corridors.

2. An extensive search in the literature as to vertebrate fauna of the restingas of southeastern Brazil and southern Bahia State in order to obtain distributional and occurrence data of species in the corridors. Because most restinga areas have been anthropically destroyed in recent years we considered only species records in the literature from the last 30 years (1970 to the present).

3. Data available in official checklists of the threatened tetrapods fauna of Brazil (IBAMA, 2003) and in regional species checklists for the states through which the corridors run, in cases in which these official checklists are available: São Paulo State (Secretaria do Meio Ambiente do Estado de São Paulo, 1998) and Rio de Janeiro State (Bergallo et al., 2000a), complemented by information available in the International Union for Conservation of Nature's Red List of threatened species (Hilton-Taylor, 2000), containing information about species whose range is within corridor limits. We also supplemented our analysis with other available checklists of endangered fauna in the Atlantic Rainforest range: Paraná State (Secretaria de Estado do Meio Ambiente do Paraná, 1995), Minas Gerais State (Machado et al., 1998), and Rio Grande do Sul State (Marques et al., 2002).

4. The authors'personal records of species previously collected or found in restingas of the two corridors.

We carried out these species inventories in the field in the restinga areas of the corridors not only to add to the knowledge of species composition and richness of the tetrapods in each restinga area, but also to record occurrences of endemics and threatened species. Species inventories along coastal restingas were made from November 1999 to March 2000. At each restinga area, inventories were made by intensively sampling the terrestrial vertebrates for three days, using the methodology proposed for rapid assessment programs (Fonseca, 2001) for vertebrate fauna. We made (1) transects within the vegetation of each restinga (about 1,000-2,000 m each for birds) to sample amphibians, reptiles, and birds; (2) an intensive search of the interior of bromeliads (amphibians and reptiles); (3) intensive samplings of leaf litter and ground- dwelling amphibians and reptiles by establishing 20 glue traps (Victor mouse ${ }^{\circledR}$ glue traps) placed inside shrubs, on the ground, and on the base of tank bromeliads; (4) transects of 200 Sherman and Tomahawk traps set on the ground (for mammals); and (5) use of mist nets (10 nets to sample birds and 4 nets for bats). We supplemented our data with information regarding specimens of some restinga species presently housed in the collections of the Museu Nacional do Rio de Janeiro and the Museum of the University of São Paulo.

\section{RESULTS AND DISCUSSION}

Along the restingas sampled in the two corridors we recorded the occurrence of a total of 22 species of amphibians, 18 of reptiles, 121 birds (including nine aquatic species) and 21 of mammals (12 nonvolant and nine bat species). The number of vertebrate species sampled varied among restingas: 24 in the restinga of Grumari, 56 in Maricá, 35 in Massambaba, 39 in Jurubatiba, 35 in Grussaí, 55 in Neves, 43 in Setiba, 28 in Guriri, 28 in Prado, and 42 in Trancoso. It is important to emphasize that, while the restinga of Praia das Neves had the highest species richness among the restingas sampled and is biologically relevant, it is at present not included in the areas of either corridor. Within the terrestrial vertebrate species recorded we found some endemics and some that are currently considered as threatened with extinction. Also, in the restingas of the Central da Mata Atlântica and Serra do Mar corridors there are terrestrial vertebrates endemic to the Atlantic Rainforest biome as a whole, and also some species endemic only to the restinga ecosystem. Five species of amphibians, six of reptiles, and one bird are endemic to the restinga habitats (Table 1).

Carvalho-e-Silva et al. (2000) considered five amphibian species as endemic to the restingas of the Brazilian southeastern and south-northeastern regions. Some species are almost totally restricted to certain localities along the coastal restingas. The leptodactylid Leptodactylus marambaiae occurs only in the Restinga da Marambaia, in the municipality of Rio de Janeiro, RJ (Izecksohn \& Carvalho-e-Silva, 2001). This restinga consists of a thin strip of sand, and is preserved only because it is an area under the control of the Brazilian army. The bromelicolous hylid Xenohyla truncata is restricted to the restingas of Rio de Janeiro State, e.g., Barra de Maricá. The hylid Scinax littorea is another species with distribution restricted to Ponta Negra, RJ. 
TABLE 1

Checklist of the vertebrate species endemic to the restingas of the Serra do Mar and Central da Mata Atlântica corridors: $a=$ restinga inventories; $b=$ previous collection by the authors; $c=$ literature; and $d=$ museum specimens.

\begin{tabular}{|c|c|}
\hline Species & Source \\
\hline $\begin{array}{l}\text { Amphibia } \\
\text { Anura } \\
\text { Hylidae } \\
\text { Xenohyla truncata (Izecksohn, 1959) } \\
\text { Scinax agilis (Cruz \& Peixoto, 1983) } \\
\text { Scinax littorea (Peixoto, 1988) } \\
\text { Bufonidae } \\
\text { Bufo pygmaeus Myers \& Carvalho, } 1952 \\
\text { Leptodactylidae } \\
\text { Leptodactylus marambaiae Izecksohn, } 1976\end{array}$ & $\begin{array}{c}\text { a, b, c, d } \\
\text { a, c, d } \\
\text { a,c,d } \\
\text { a, b, c, d } \\
\text { c, d. }\end{array}$ \\
\hline $\begin{array}{l}\text { Reptilia } \\
\text { Lacertilia } \\
\text { Tropiduridae } \\
\text { Liolaemus lutzae Mertens, } 1938 \\
\text { Teiidae } \\
\text { Cnemidophorus littoralis Rocha, Araújo, Vrcibradic \& Mamede, } 2000 \\
\text { Cnemidophorus nativo Rocha, Bergallo \& Peccinini-Seale, 1997 } \\
\text { Scincidae } \\
\text { Mabuya caissara Rebouças-Spieker, } 1974 \\
\text { Amphisbaenia } \\
\text { Amphisbaenidae } \\
\text { Amphisbaena nigricauda Gans, } 1966 \\
\text { Amphisbaena } \text { sp. (Restinga de Grumari) } \\
\text { Serpentes } \\
\text { Viperidae } \\
\text { Bothrops leucurus Wagler, } 1824 \text { [= B. pradoi (Hoge, 1948)] }\end{array}$ & $\begin{array}{c}\text { a, b, c, d } \\
\text { a, b, c, d } \\
\text { a, b, c, d } \\
\text { a, b, c, d } \\
\text { b, c, d } \\
\text { b } \\
\text { a, b, c }\end{array}$ \\
\hline $\begin{array}{l}\text { Aves } \\
\text { Passeriformes } \\
\text { Thamnophilidae } \\
\text { Formicivora littoralis Gonzaga \& Pacheco, } 1990\end{array}$ & $\mathrm{a}, \mathrm{c}, \mathrm{d}$ \\
\hline
\end{tabular}

The bufonid Bufo pygmaeus occurs in restingas of Rio de Janeiro State such as Jurubatiba and Grussaí (Rocha et al., 2002) and Marambaia, Maricá, and Arraial do Cabo to São João da Barra (Carvalho-eSilva et al., 2000). This species constitutes another example of anuran endemism in restinga habitats (Carvalho-e-Silva et al., 2000; Rocha et al., 2003). Carvalho-e-Silva et al. (2000) argue that the report of this species' occurrence in Argentina must be "regarded with caution" because it is probably a different species from that of the restingas of Rio de Janei- ro State. In a recent review, concluded that $B$. pygmaeus is actually an endemic species of restinga habitats in Rio de Janeiro State. The hylid Scinax agilis, whose type locality is Ibiriba, municipality of Linhares, ES (Cruz \& Peixoto, 1983), is restricted to some restingas (Trancoso is an example) of Espírito Santo and Bahia states (unpubl. data of the authors). Thus, we can recognize a group of amphibians endemic to the restingas of the Serra do Mar corridor (Leptodactylus marambaiae, Xenohyla truncata, Scinax littorea, and Bufo pygmaeus) and 
another endemic to restingas in the Central da Mata Atlântica corridor (at present, only Scinax agilis is in this group).

Of the six species of reptiles endemic to the restingas in the corridors, three are lizards, two are amphisbaenians, and one is a snake. As in the case of the amphibians, two groups of endemic reptile species may be recognized. One group of endemic species occurs in the restingas of the Serra do Mar corridor (Liolaemus lutzae, Cnemidophorus littoralis, and Amphisbaena sp., which is known only from the Grumari restinga), while the other is restricted to the Central da Mata Atlântica corridor (Cnemidophorus nativo, Bothrops leucurus (= B. pradoi), and Amphisbaena nigricauda). Bothrops leucurus $(=B$. pradoi; see Puorto et al., 2001) occurs from Espírito Santo State northwards to the southern portion of Alagoas State, with most of its geographic distribution inside the Central da Mata Atlântica corridor.

The tendency of each corridor to have a specific group of endemic species is illustrated in the case of a single lizard genus, Cnemidophorus, in which one species is restricted to restingas of the Serra do Mar corridor (C. littoralis) whereas another species is characteristic of the restingas in the Central da Mata Atlântica corridor (C. nativo). The tropidurid lizard Liolaemus lutzae is endemic to the beach habitats of Rio de Janeiro State, occurring from the Restinga da Marambaia eastward to Cabo Frio. The teiid lizard Cnemidophorus littoralis is restricted to restingas from Maricá to Grussaí (Rocha, 2000). The recent descriptions of $C$. littoralis and C. nativo, and the recent discovery of a new amphisbaenid species (Amphisbaena sp.) from Grumari restinga in Rio de Janeiro municipality, RJ (J. Duarte Barros Filho, unpublished data), reveal present lack of knowledge of the vertebrate fauna of Brazilian coastal restingas. Cnemidophorus nativo is a parthenogenetic lizard restricted to restingas from northern Espírito Santo to southern Bahia State (Rocha et al., 1997, 1999). In the same group of restingas, from the northern Espírito Santo State coast to the south of Bahia State, the snake Bothrops leucurus (= B. pradoi) (Puorto et al., 2001) and the amphisbaenian Amphisbaena nigricauda, which together with $C$. nativo are endemic (Gans, 1966; Rocha, 1998, 2000), indicate that the restingas in this part of the Central da Mata Atlântica corridor are an important areas of reptilian endemism. It is worthy of note that close to the northern portion of the Central da Mata Atlântica corridor a new species of coastal endemic lizard of the genus Cnemidophorus was recently described: C. abaetensis from the Restinga de Abaeté in the region of Salvador, Bahia (Dias et al., 2002).

For birds, the only species endemic to restinga habitats is Formicivora littoralis, which occurs in Rio de Janeiro State (Serra do Mar corridor). At present, no other bird species is known to be endemic to restingas in the Central da Mata Atlântica corridor.

The rodent Trinomys eliasi was until recently considered to be endemic to the restinga of Maricá, RJ, in Serra do Mar corridor. However, it was found not long ago in the Reserva Biológica de Poço das Antas, RJ (F. Fernandez, personal communication), which suggests that it is not restricted to restinga habitats but rather to some regions of the Atlantic Forest coastal plain of Rio de Janeiro State. For this reason, we do not consider this species as endemic to restinga habitats. Apparently, there is no endemic mammal species in the restingas (Cerqueira et al., 1990; Cerqueira, 2000), as the species occurring in them come from forested areas of the Atlantic Rainforest biome and/or other open areas, such as cerrado (savannah-like vegetation). Oryzomys subflavus, a taxon whose species boundaries are poorly known, is a common inhabitant of restingas and highly variable both chromosomally and morphologically (Bonvicino \& Moreira, 2001).

For restingas, among the four tetrapod groups studied, reptiles have the greatest number of endemic species. This may result from characteristics of this group and also from past events favoring the evolution of endemisms in these vertebrates.

Analyzing the geographic ranges of endemisms found for terrestrial vertebrates throughout the coast of Serra do Mar and Central da Mata Atlântica biodiversity corridors, we can observe that endemic rates differ greatly among restingas, only some of which harbored endemic species (Fig. 1). For example, in the southern part of Serra do Mar corridor from the Restinga da Marambaia to the south of this corridor, endemism of terrestrial vertebrates is considerably restricted. In this part of the corridor, the Serra do Mar reaches the coast and, consequently, restingas and sandy beaches are not found along many portions. Basically, in this region the restingas are restricted to the southern part of Ilha Grande, in Rio de Janeiro State (restingas of Praia do Sul and Praia do 
Leste), and to Ilha do Cardoso and Estação Ecológica da Juréia in São Paulo State. The lizard Mabuya caissara is the only endemic species of terrestrial vertebrates in the sandy habitats of the northern coast of São Paulo State (not considering insular habitats without restinga formations) (Rebouças-Spieker, 1974; Vanzolini \& RebouçasSpieker, 1976). The data show that some restingas harbor a relatively large number of endemic species (Fig. 1), and, as a result, two main regions of endemism can be identified along the restingas of both corridors (Fig. 1):

1. the coastal restingas from the north of Espírito Santo State (ES) to south of Bahia State (between Linhares, ES, and Trancoso (Bahia)), in the Central da Mata Atlântica corridor and;

2. the coastal region between the restingas of Maricá and Jurubatiba, Rio de Janeiro State, in the Serra do Mar corridor.

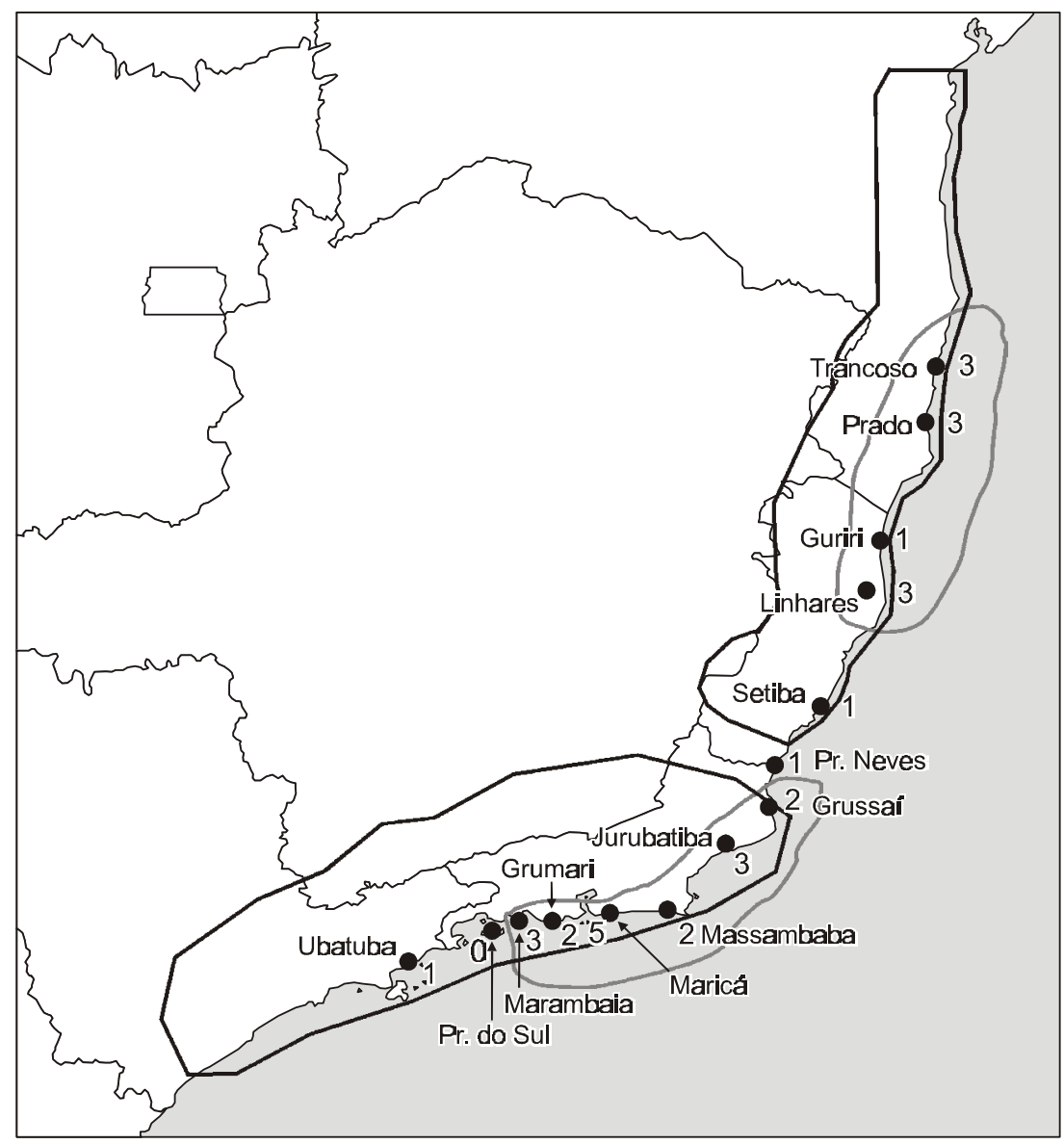

Fig. 1 - Occurrence of endemisms of amphibians, reptiles, birds, and mammals along the restinga areas of the Serra do Mar and the Central da Mata Atlântica biodiversity corridors (delimited by a solid line). The two areas delimited by the dashed line have the higher number of endemic vertebrates. 
The region between northern Espírito Santo State and the southeastern coast of Bahia State is considered to have been a Pleistocene refuge (Jackson, 1978) during one of the most ancient marine transgressions (Flexor et al., 1984). The climatic changes that produced these refuges (Vanzolini \& Williams, 1981) and the changes in sea level along the Brazilian coast have significantly affected the occurrence and extent of sandy coastal habitats (Bigarella, 1965a, b, 1971; Bigarella et al., 1966; Martin et al., 1980). These variations were probably important events affecting the evolutionary processes of coastal species and resulting in differentiation processes of vertebrates along the coast of both corridors (Vanzolini \& Ab'Saber, 1968; Vanzolini \& Rebouças-Spieker, 1976; Jackson, 1978; Marroig \& Cerqueira, 1997), albeit at greater rates in some regions (Rocha, 2000). As a result, many species differentiated in these portions due to distribution discontinuities. Although there is a tendency in restingas of both biodiversity corridors to harbor a distinct group of endemic vertebrates, ignorance with respect to the evolutionary processes generating them rules out knowing if these endemisms are the result of historical refugiae.

Restingas are one of the least known habitats within the Atlantic Rainforest domain. For example, the restinga of Barra de Maricá, RJ, is one of the few in either biodiversity corridors in which a considerable sampling effort focusing on amphibians, reptiles, birds, and mammals has been carried out (Britto-Pereira et al., 1988; Cerqueira et al., 1990; Rocha \& Vrcibradic, 1998; Rocha et al., 2000a; Gonzaga et al., 2000). But recent preliminary studies in a few more restingas have led to the discovery of new vertebrate species (Rocha et al., 1997, 2000b; Dias et al., 2002). The occurrence of endemic species of vertebrates, together with the discovery of a considerable number of new species in the last five years, emphasizes the importance of restingas as habitats on behalf of which conservation efforts must be made. Based on present evidence we can expect that increased sampling efforts in restinga habitats will result in the discovery not only of new species but also of new endemisms.

The total number of terrestrial vertebrates we found to be endemic to restingas suggests that the rate of endemisms in this environment is relatively low when compared to that of the Atlantic Rainforest biome as a whole (Cerqueira, 2000; Gonzaga et al., 2000; Rocha, 2000), which is seemingly a result of the relatively late age of restinga habitats (Quaternary).

\section{Threatened terrestrial vertebrates}

Six species of terrestrial vertebrates considered to be threatened with extinction are found in the restingas of Serra do Mar and Central da Mata Atlântica biodiversity corridors. No threatened species of amphibians are listed for restingas. However, considering the rapid degradation process continuing in these habitats, we believe that a set of threatened amphibian species in restingas will, in the near future, result from updates in the status of these animals.

Among reptiles, the lizard Liolaemus lutzae is the only species considered threatened with extinction in restingas in the Serra do Mar corridor (Bergallo et al., 2000a; Rocha et al., 2000c). Throughout this species' geographic distribution, the coastal vegetation is systematically being destroyed due to anthropic disturbances of different scales and frequencies (Rocha \& Bergallo, 1992; Rocha et al., 2000c). As a result, the remaining populations of $L$. lutzae are increasingly being restricted to some isolated areas, and showing locally declining populations (Rocha \& Bergallo, 1992; Rocha et al., 2000c).

Among birds, there are presently three species considered as threatened with extinction in the restinga areas of the two corridors: Formicivora littoralis, Mimus gilvus, and Schistochlamys melanopis (categorized as extinct for Rio de Janeiro State, Alves et al., 2000). Formicivora littoralis, considered as threatened with extinction at global (Collar et al., 1992; BirdLife International, 2000), national (IBAMA, 2003), and regional levels (Alves et al., 2000), has recently been listed in the Brazilian Checklist of Threatened Fauna (IBAMA, 2003) as critically endangered. This classification is because this species is endemic and has a highly restricted geographic range (Collar et al., 1992; Alves et al., 2000; BirdLife International, 2000).

Formicivora littoralis is endemic to restinga habitats of Rio de Janeiro State and has been recorded in the restinga of Massambaba, RJ, in 2000, where a pair was captured through the use of mist nets (M.A.S. Alves, unpublished data). As a result, we stress the urgent need for effective conservation measures in this restinga area, which is presently the object of strong anthropic pressure.

Regarding Mimus gilvus, the species is not presently threatened at a national level but was considered threatened on a regional scale in Rio de 
Janeiro State (Alves et al., 2000). The endemic Atlantic Forest taxon, M. gilvus antelius, which occurs in Rio de Janeiro State, is closely associated with southeastern Brazilian restingas (Gonzaga et al., 2000) Although Porto \& Teixeira (1984) had recorded the species in the area one decade before, Gonzaga et al. (2000) did not record the occurrence of $M$. gilvus after a 6-year study (1990-96) in the Restinga de Maricá, suggesting the eradication of this species in the area owing principally to, as suggested by Gonzaga et al. (2000), its capture for the cage-bird trade. As a result, it is strongly recommended that this area, which is presently an environmentally protected area (Área de Proteção Ambiental), be converted into an adequately protected conservation area (Área de Conservação de Proteção Integral). The recent demarcation of Parque Nacional da Restinga de Jurubatiba in 1998 is of special importance for the protection of this threatened species in Rio de Janeiro State. It is also necessary to monitor this bird species in this area and in the Restinga da Marambaia, where it still occurs (Alves, 2000). There is little information available on M. gilvus antelius, except for a study on its feeding habits in the Restinga da Marambaia (Maciel \& Costa, 1997).

Regarding the mammals of the restingas within the corridors, the spiny rat Trinomys eliasi is presently classified on the Rio de Janeiro State checklist as a threatened species (Bergallo et al., 2000b). Up until now, Trinomys eliasi is known only from the Barra de Maricá restinga and from the Reserva Biológica de Poço das Antas.

When the distribution of terrestrial threatened vertebrate species of the restingas of the Serra do Mar and the Central da Mata Atlântica corridors are analyzed, they can be labeled collectively as a region of special relevance, where a considerable number of threatened of terrestrial vertebrates are found. This region is located between the restinga of Maricá and the restinga of Jurubatiba, both in Rio de Janeiro State. However, areas of concern are also located within the Central da Mata Atlântica corridor in the states of Espírito Santo and Bahia. In these regions, occurrence of threatened vertebrate species has not been recorded, and these restingas still do not have regional checklists of their threatened fauna, although an analysis of threatened fauna is presently being carried out in Espírito Santo State. Therefore, the lack of threatened vertebrate species in the restinga areas of these states may simply be a consequence of lack of information on the present conservation status of the vertebrate species. However, based on data currently available on threatened species of terrestrial vertebrates, the region of the restinga areas of the Serra do Mar corridor previously mentioned (from Maricá to Jurubatiba) can be regarded specially relevant for the conservation of vertebrate species of the corridor restingas. We strongly recommend efforts to develop checklists of threatened faunas in Espírito Santo and Bahia states.

Acknowledgements - This study is portion of the results of the Programa de Ecologia, Conservação e Manejo de Ecossistemas do Sudeste Brasileiro and the Southeastern Brazilian Vertebrate Ecology Project (Vertebrate Ecology Laboratory), both of the Setor de Ecologia, Instituto de Biologia, Universidade do Estado do Rio de Janeiro. This study resulted from several years of study of the vertebrates in some brazilian restingas and was supported by grants from the Conselho Nacional do Desenvolvimento Científico e Tecnológico (CNPq - Processes 307653/2003-0, 302405/02-0, and 477981/03-8) and from the Fundação de Amparo à Pesquisa do Estado do Rio de Janeiro (FAPERJ) to the authors. It was also partially supported by grants from the CBC - Mata Atlântica of the Conservation International - Brazil and Idea Wild (an American NGO). We especially thank all of our students of the Scientific Initiation Program, and of the Master's and Doctoral programs, for field assistance in the areas that we have been studying throughout recent years. We also thank the multi-faceted collaboration of Clinton Jenkins during our studies on the Atlantic Rainforest and for his help with the figure in this paper. D. Vrcibradic, T. P. Moulton, and D. Gettinger kindly revised the manuscript and offered helpful suggestions.

\section{REFERENCES}

AlVES, M. A. S., PACHECO, J. F., GONZAGA, L. P., CAVALCANTI, R. B., RAPOSO, M., YAMASHITA, C., MACIEL, N. C. \& CASTANHEIRA, M., 2000, Aves. pp. 113-124. In: H. G. Bergallo, C. F. D. Rocha, M. A. S. Alves \& M. Van Sluys (orgs.), A fauna ameaçada de extinção do Estado do Rio de Janeiro. Editora da Universidade do Estado do Rio de Janeiro (EdUerj), Rio de Janeiro, 166p.

ALVES, M. A. S., 2000, Sistemas de acasalamento em aves: as restingas como ambientes apropriados para estudos. pp. 179-188. In: F. A. Esteves \& L. D. Lacerda (eds.), Ecologia de restingas e lagoas costeiras. NUPEM/UFRJ, Macaé, Rio de Janeiro.

ARAÚJO, D. S. D., 1991, As restingas dizimadas. Ecorio, 1(40): 31-32.

ARAÚJO, D. S. D., 2000, Análise florística e fitogeográfica das restingas do Estado do Rio de Janeiro. Tese de Doutorado, Departamento de Ecologia, Universidade Federal do Rio de Janeiro, Rio de Janeiro, 169p.

ARAÚJO, D. S. D. \& LACERDA, L. D., 1987, A natureza das restingas. Ciência Hoje, 6(33): 42-48.

ATLAS DOS REMANESCENTES FLORESTAIS DA MATA ATLÂNTICA, 2001, SOS Mata Atlântica/INPE. 
BERGALLO, H. G., ROCHA, C. F. D., ALVES, M. A. S. \& VAN SLUYS, M. (orgs.), 2000a, A fauna ameaçada de extinção do Estado do Rio de Janeiro. Editora Universidade do Estado do Rio de Janeiro (EdUerj), Rio de Janeiro, 166p.

BERGALlO, H. G., GEISE, L., BONVICINO, C. R., CERQUEIRA, R., D'ANDREA, P. S., ESBERÁRD, C. E., FERNANDEZ, F. A. S., GRELLE, C. E., PERACCHI, A. SICILIANO, S. \& VAZ, S. M., 2000b, Mamíferos. pp. 125135. In: H. G. Bergallo, C. F. D. Rocha, M. A. S. Alves \& M. Van Sluys (orgs.), A fauna ameaçada de extinção do Estado do Rio de Janeiro. Editora da Universidade do Estado do Rio de Janeiro (EdUerj), Rio de Janeiro, 166p.

BERNARDES, A., MACHADO, A. B. M. \& RYLANDS, A. B., 1990, Fauna brasileira ameaçada de extinção. Fundação Biodiversitas para a Conservação da Diversidade Biológica, Belo Horizonte, Minas Gerais, 65p.

BIGARELLA, J. J., 1965a, Subsídios para o estudo de variações de nível oceânico no Quaternário brasileiro. An. Acad. Bras. Ciênc., 37: 263-278.

BIGARELLA, J. J., 1965b, Sand-ridge structures from Paraná Coastal Plain. Marine Geology, 3: 269-278.

BIGARELLA, J. J., 1971, Variações climáticas no Quaternário superior do Brasil e sua datação radiométrica pela datação do carbono 14. Paleoclimas, 1: 1-22.

BIGARELLA, J. J., FREIRE, S. S., SALAMUNI, R. \& VIANA, R., 1966, Contribuição ao estudo dos sedimentos praias recentes II. Praias de Matinhos e Caiobá. Universidade Federal do Paraná. Geol. Física, v. 6.

BIRDLIFE INTERNATIONAL, 2000, Threatened birds of the world. Lynx Edicions and BirdLife International, Barcelona and Cambridge, UK, 852p.

BONVICINO, C. R. \& MOREIRA, M. A. M., 2001, Molecular philogeny of the genus Oryzomys (Rodentia, Sigmodontinae) based on cytochrome b DNA sequences. Mol. Phylog. Evol., 18(2): 282-292.

BRITTO-PEREIRA, M. C., CERQUEIRA, R., SILVA, H. R. \& CARAMASCHI, U., 1988, Anfíbios anuros da restinga de Maricá - RJ: levantamento e observações sobre a atividade reprodutiva das espécies registradas. An. Sem. Reg. São Carlos, VI: 295-306.

CARVALHO-E-SILVA, S. P., IZECKSOHN, E. \& CARVALHOE-SILVA, A. M. P. T., 2000, Diversidade e ecologia de anfíbios em restingas do sudeste brasileiro. pp. 89-97. In: F. A. Esteves \& L. D. Lacerda (eds.), Ecologia de restingas e lagoas costeiras. NUPEM/UFRJ, Macaé, Rio de Janeiro.

CENTER FOR APPLIED BIODIVERSITY SCIENCE, 2000, Designing sustainable landscapes - the brazilian atlantic forest. Conservation international and instituto de estudos sócio-ambientais do sul da Bahia. 29p.

CERQUEIRA, R., 2000, Biogeografia das restingas. pp. 6575. In: F. A. Esteves \& L. D. Lacerda (eds.), Ecologia de restingas e lagoas costeiras. NUPEM/UFRJ, Macaé, Rio de Janeiro, Brasil.

CERQUEIRA, R., FERNANDEZ, F. A. S. \& NUNES, M. F. Q. S., 1990, Mamíferos da restinga de Barra de Maricá. Pap. Avuls. Zool. S. Paulo, 37: 141-157.
COLLAR, N. J., GONZAGA, L. P., KRABBE, N., MADROÑO NIETO, A., NARANJO, L. G., PARKER III, T. A. \& WEGE, D. C., 1992, Threatened birds of the Americas: the ICBP/ IUCN Red Data Book. International Council for Bird Preservation, Cambridge, UK.

CRUZ, C. A. G. \& PEIXOTO, O., 1983, Uma nova espécie de Hyla do Estado do Espírito Santo, Brasil (Amphibia, Anura, Hylidae). Rev. Bras. Biol., 42(4): 721-724.

DIAS, E. J. R., ROCHA, C. F. D. \& VRCIRBRADIC, D., 2002, A new Cnemidophorus (Squamata; Teiidae) from Bahia State, Northeastern Brazil. Copeia, 4: 1070-1077.

FLEXOR, J. M., MARTIN, L., SUGUIO, K. \& DOMINGUEZ, J. M. L., 1984, Gênese dos cordões litorâneos na parte central da costa brasileira. In: L. D. Lacerda, D. S. D. Araujo, R. Cerqueira \& B. Turcq (eds.), Restingas: origem, estrutura e processos. Centro Editorial da Universidade Federal Fluminense, CEUFF, Niterói, Rio de Janeiro.

FONSECA, G. A. B., 2001, Proposta para um programa de avaliação rápida em âmbito nacional. pp. 150-156. In: I. Garay \& B. Dias (orgs.), Conservação da biodiversidade em ecossistemas tropicais. Editora Vozes, Petrópolis.

GANS, C., 1966, Studies on Amphisbaenids (Amphisbaenia, Reptilia). 3 - The small species from southern South America commonly identified as Amphisbaena darwini. Bull. Am. Mus. Nat. Hist., 134(3): 185-260.

GONZAGA, L. P., CASTIGLIONI, G. D. A. \& REIS, H. B. R., 2000, Avifauna das restingas do Sudeste: Estado do conhecimento e potencial para futuros estudos. pp. 151-163. $I n$ : F. A. Esteves \& L. D. Lacerda (eds.), Ecologia de restingas e lagoas costeiras. NUPEM/UFRJ, Macaé, Rio de Janeiro.

HAY, J. D., LACERDA, L. D. \& TAN, A. L., 1981, Soil cation increase in a tropical sand dune ecosystem due to a terrestrial bromeliad. Ecology, 62(5): 1392-1395.

HILTON-TAYLOR, C. (comp.), 2000, 2000 IUCN Red list of threatened species CD-ROM. Gland, Suiça e Cambridge, UK, IUCN.

IBAMA, 2003, Lista oficial da fauna brasileira ameaçada de extinção. Instituto Brasileiro do Meio Ambiente e dos Recursos Naturais Renováveis (IBAMA), Fundação Biodiversitas e Conservation International Brasil. http:// www.biodiversitas.org.br/t_ameaca/listaibama2003.htm.

IZECKSOHN, E. \& CARVALHO-E-SILVA, S. P., 2001, Anfibios do município do Rio de Janeiro. Editora UFRJ, Rio de Janeiro, $147 \mathrm{p}$.

JACKSON, J. F., 1978, Differentiation in the genera Enyalius and Strobilurus (Iguanidae): Implications for Pleistocene climatic changes in Eastern Brazil. Arq. Zool. S. Paulo, 30(1): $1-79$.

MACHADO, A. B. M., FONSECA, G. A. B., MACHADO, R. B., AGUIAR, L. M. S. \& LINS, L. V. (eds.), 1998, Livro vermelho das espécies ameaçadas de extinção da fauna de Minas Gerais. Belo Horizonte, Fundação Biodiversitas, 605p.

MACIEL, N. C. \& COSTA, R. C. F., 1997, Alimentação de Mimus gilvus e Mimus saturninus, município do Rio de Janeiro, RJ, Brasil: dados preliminares. Resumo do VI Congresso Brasileiro de Ornitologia. Universidade Federal de Minas Gerais, Belo Horizonte, MG, p. 196. 
MARQUES, A. A. B., FONTANA, C. S., VÉLEZ, E., BENCKE, G. A., SCHNEIDER, M. \& DOS REIS, R. E. (orgs.), 2002, Lista das espécies da fauna ameaçadas de extinção no Rio Grande do Sul. Decreto no 41.672, de 11 de junho de 2002. Porto Alegre, FZB/MCT-PUCRS/PANGEA, 52p. (Publicações Avulsas FZB, 11).

MARROIG, G. \& CERQUEIRA, R., 1997, Plio-Peistocene South American History and the Amazon Lagoon Hypothesis: a piece in the puzzle of Amazonian diversification. J. Comp. Biol., 2(2): 103-119.

MARTIN, L., BITTENCOURT, A. C. S. P., VILAS BOAS, G. S. \& FLEXOR, J. M., 1980, Mapa geológico do Quaternário costeiro do Estado da Bahia. Coordenação de Produção Mineral, Secretaria de Minas e Energia, Governo do Estado da Bahia, 14p.

MINISTÉRIO DO MEIO AMBIENTE, 2002, Avaliação $e$ identificação de áreas prioritárias para a conservação, utilização sustentável e repartição dos benefícios da biodiversidade nos biomas brasileiros. Brasília: MMA/SBF, 404p.

PORTO, F. C. S. \& TEIXEIRA, D. M., 1984, Um estudo comparativo preliminar sobre as avifaunas das restingas do leste do Brasil. In: L. D. Lacerda, D. S. D. Araujo, R. Cerqueira \& B. Turcq (eds.), Restingas: origem, estrutura e processos. Centro Editorial da Universidade Federal Fluminense, CEUFF, Niterói, Rio de Janeiro.

PUORTO, G., SALOMÃO, M. G., THEAKSTON, R. D. G., THORPE, R. S., WARRELL, D. A. \& WÜSTER, W., 2001, Combining mitochondrial DNA sequences and morphological data to infer species boundaries: Phylogeography of lancehead pitvipers in the Brazilian Atlantic Forest, and the status of Bothrops pradoi (Squamata: Serpentes: Viperidae). J. Evol. Biol., 14: 527-538.

REBOUÇAS-SPIEKER, R., 1974, Distribution and differentiation of animals along the coast and the islands of São Paulo, Brazil. 2. Lizards of the genus Mabuya (Sauria, Scincidae). Pap. Avuls. Zool. S. Paulo, 28: 197-240.

ROCHA, C. F. D., 1998, Composição e organização da comunidade de répteis da área de Mata Atlântica da região de Linhares, Espírito Santo. Anais do VIII Seminário Regional de Ecologia, São Carlos, pp. 869-881.

ROCHA, C. F. D., 2000, Biogeografia de répteis de restinga: distribuição, ocorrência e endemismos. pp. 99-116. In: F. A. Esteves \& L. D. Lacerda (eds.), Ecologia de restingas e lagoas costeiras. NUPEM/UFRJ, Macaé, Rio de Janeiro.

ROCHA, C. F. D. \& BERGALlO, H. G., 1992, Population decrease: the case of liolaemus lutzae, an endemic lizard of Southeastern Brazil. Ciência e Cultura, 44(1): 52-54.

ROCHA, C. F. D. \& BERGALLO, H. G., 1997, Intercommunity variation in the distribution of abundance of dominant lizard species in restinga habitats. Ciência e Cultura, 49(4): 269274.

ROCHA, C. F. D., BERGALLO, H. G. \& PECCININI-SEALE, D. M., 1997, Evidence of a unisexual population of the Brazilian whiptail lizard genus Cnemidophorus (Teiidae) with description of a new species. Herpetologica, 53: 374-382.
ROCHA, C. F. D. \& VRCIBRADIC, D., 1998, Reptiles as predators and as preys in a restinga habitat of southeastern Brazil. Ciência e Cultura, 50(5): 364-368.

ROCHA, C. F. D., MENEZES, V. A., BERGALLO, H. G. \& DUTRA, G. F., 1999, Cnemidophorus nativo (Brazilian Whiptail: Geographic distribution. Herp. Review, 30(2): 109.

ROCHA, C. F. D., VRCIBRADIC, D. \& ARAUJO, A. F. B., 2000a, Ecofisiologia de répteis de restinga. pp. 117-149. In: F. A. Esteves \& L. D. Lacerda (eds.), Ecologia de restingas e lagoas costeiras. NUPEM/UFRJ, Macaé, Rio de Janeiro.

ROCHA, C. F. D., ARAÚJO, A. F. B., VRCIBRADIC, D. \& MAMEDE-DA-COSTA, E. M., 2000b, New Cnemidophorus (Squamata; Teiidae) from coastal Rio de Janeiro, southeastern Brazil. Copeia 2000: 501-509.

ROCHA, C. F. D., VAN SLUYS, M., PUORTO, G., FERNANDES, R., BARROS-FILHO, J. D., ROCHA E SILVA, R., NÉO, F. A. \& MELGAREJO, A., 2000c, Répteis. pp. 79-166. In: H. G. Bergallo, C. F. D. Rocha, M. A. S. Alves \& M. Van Sluys (orgs.). A fauna ameaçada de extinção do Estado do Rio de Janeiro. Editora da Universidade do Estado do Rio de Janeiro (EdUerj), Rio de Janeiro.

ROCHA, C. F. D., BERGALLO, H. G., VAN SLUYS, M. \& ALVES, M. A. S., 2003, A biodiversidade nos grandes remanescentes florestais do Estado do Rio de Janeiro e nas restingas da Mata Atlântica. RiMa, São Carlos, São Paulo, $160 \mathrm{p}$.

SECRETARIA DE ESTADO DO MEIO AMBIENTE DO PARANÁ, 1995, Lista vermelha de animais ameaçados de extinção do Estado do Paraná. SEMA/GTZ, Curitiba.

SECRETARIA DO MEIO AMBIENTE DO ESTADO DE SÃO PAULO, 1998, Fauna ameaçada no Estado de São Paulo. Documentos Ambientais - Série Probio/SP, 56p.

SOS MATA ATLÂNTICA/INPE/INSTITUTO SOCIOAMBIENTAL, 1998, Atlas da evolução dos remanescentes florestais e ecossistemas associados no domínio da Mata Atlântica no período 1990-1995. SOS Mata Atlântica/INPE/Instituto SocioAmbiental, São Paulo.

SOS MATA ATLÂNTICA/INPE, 2001, Atlas dos remanescentes florestais da mata atlântica, período 1995-2000. São Paulo.

VANZOLINI, P. E. \& AB'SABER, A., 1968, Divergence rate in South American lizards of the genus Liolaemus (Sauria: Igauanidae). Pap. Avuls. Zool., São Paulo, 21: 205-208.

VANZOLINI, P. E. \& REBOUÇAS-SPIEKER, R., 1976, Distribution and differentiation of animals along the coast of the State of São Paulo, Brazil. 3. Reproductive differences between and within Mabuya caissara and M. macrorhyncha (Sauria: Scincidae). Papéis Avuls. Zool. S. Paulo, 29(15): 95-109.

VANZOLINI, P. E. \& WILLIAMS, E. E., 1981, The vanishing refuge: a mechanism for ecogeographic speciation. Pap. Avuls. Zool., 34(23): 251-255. 